\title{
HAMANGIOMAS INVOLVING THE SPINAL EPIDURAL SPACE
}

\author{
BY \\ A. N. GUTHKELCH \\ From the University Department of Neurosurgery, Manchester Royal Infirmary
}

(RECEIVED APRIL 23, 1948)

\section{Introduction}

The purpose of the present communication is to collect as completely as possible the sources of information relating to a rare group of tumours of the spinal epidural space-those of blood-vessel origin*-and to record eight previously unpublished examples of this condition. It has been thought helpful to include in the study not only those tumours which arise primarily within the epidural tissue itself, but also those which extend into or invade the epidural space from an adjacent vertebra ; for as the analysis of the known cases proceeded, it became obvious that there were intermediate stages between the purely epidural and the purely vertebral hæmangioma.

The frequency of occurrence of any rare condition is always hard to estimate, and few writers have seen more than one or two epidural hæmangiomas. However, Rassmussen and others (1940) mention the occurrence of twenty-eight epidural tumours of blood-vessel origin among 557 intra-spinal neoplasms in the records of the Mayo Clinic ; and Elsberg (1941) found four in his personal series of eighty-five epidural tumours of the spine.

Purely epidural hæmangiomas seem almost always to occur in the thoracic spine. In histological structure they vary from cavernous hæmangiomas to the less mature hæmangioendotheliomas and hæmangioblastomas, some of which latter have shown a tendency to spread through the intervertebral foramina into the extraspinal tissues and to recur locally after removal. Reference to the literature has revealed fourteen authenticated examples of epidural hæmangioma of mature type (Liebscher, 1901 ; Devic and Tolot, 1906 ; Bériel, 1922 ; Balado and Morea, 1927 ; Rand, 1927 (Case 1); Petit-Dutaillis and Christophe, 1931 ; Bucy, 1932 ; Mixter, 1932 (Case 6); Johnston, 1938 ; Elsberg, 1941 ( 2 cases); López Ibor and Peraita, 1941 ; Wyburn-Mason, 1943 (Case 46) ; Grapiolo

* The interested reader may also consult the important reviews of Globus and Doshay (1929), Antoni(1936), and Turner and Kernohan (1941).

D and Morea, 1944). Bériel's (1922) case was further discussed by Cornil and Mosinger (1932), but these writers did not, as has sometimes been stated, bring forward any new examples. Wyburn-Mason (1943) cited as Cases 47 and 48 in his monograph two further examples observed by Professor Dott at Edinburgh, but without giving any details. This, however, is evidently a misunderstanding (Dott, 1947), and the only example of a mature epidural hæmangioma seen at Professor Dott's Clinic is now by permission published for the first time below (Case 1). Two other examples, one from Mr. W. R. Henderson's Clinic at Leeds, and one from Mr. A. Sutcliffe Kerr at Liverpool, are also published with their permission (Cases 6 and 8), thus raising the total number of recorded cases of purely epidural hæmangioma to seventeen.

Less mature tumours, hæmangioendotheliomas and hæmangioblastomas, have been reported by Dandy (1925), Naffziger and Brown (1933 ; 3 cases), P. Guillain (1933), Kaplan (1935, 1942), Elsberg (1941), and Wyburn-Mason (1943 ; Cases 62 to 65). Wyburn-Mason, again evidently by misunderstanding, also refers to two examples seen by Professor Dott and numbers them in his monograph as Cases 56 and 57, but in fact Professor Dott has only seen one example (Dott, 1947) which is now published by permission below (Case 2), together with a recent case from this department (Case 5). The number of authenticated cases of epidural hæmangioendothelioma or hæmangioblastoma is therefore fourteen.

It may be added that all these tumours except one (Wyburn-Mason's Case 63) occurred in the thoracic spine and that several cases of predominantly mature tumours were noticed to show here and there some blood vessels of new formation (which incidentally justifies their description as tumours rather than as telangiectases).

Finally there are those blood-vessel tumours of the vertebræ themselves, which are associated with epidural hæmangiomas as well. Some reference to the recorded cases will be made below. It is inter- 
esting that although only three-fifths of the 579 cases of vertebral hæmangioma examined in Schmorl's laboratory occurred in the thoracic spine (Junghanns, 1932a), yet proved epidural extensions of vertebral hæmangiomas have been found only in the thoracic region. Vertebral hæmangiomas themselves are almost always mature in type, but a case of hæmangioendothelioma of the vertebra with an epidural extension is recorded here (Case 3). The others, Cases 4 and 7 , are both of a mature vertebral hæmangioma with a histologically similar epidural extension.

Epidural metastases from primary malignant blood-vessel tumours occurring elsewhere in the body have occasionally been recorded (Shenkin and others, 1945), but no examples occurred in the present series.

\section{Case Reports}

Case 1: Epidural Hæmangioma.-A woman of 37 gave a history of pain in the back for nine months with a more recent onset of fairly severe paraplegia. At operation (1925) by Professor Dott, she was found to have an angio-lipoma of the epidural space extending from the second to the sixth thoracic vertebræ and dipping into the intervertebral foramina. It was completely removed(Fig 1 ). Microscopic examination showed a cavernous hæmangioma with a very fine connective-tissue stroma containing fat cells (Fig. 2). The patient made a good recovery but with considerable residual spasticity. This spasticity disappeared dramatically nearly four years later after an attack of influenza, and when last seen in 1932 she had remained very well.

Case 2 : Epidural Hremangioendothelioma.-A man of 39 was first seen in December, 1929. He gave an eight-week history of root pains at the level of the eighth thoracic nerves, followed by progressive paraplegia. At operation by Professor Dott a localized tumour was removed from the epidural space at the expected level. Histological examination of it showed a hæmangioendothelioma with pronounced extravascular endothelial cell development and marked hyaline change around some of the vessels. The patient unfortunately died of pulmonary embolism eight days after the operation.

Case 3 : Epidural and Vertebral Hæmangioendothelioma.-A girl aged 17 was admitted to Professor Jefferson's neurosurgical unit at Manchester Royal Infirmary on Oct. 5, 1942, with a history of gradual onset of weakness of both legs which had commenced six months before. She had not walked for four months. Six weeks before admission she began to feel " pins and needles" in both legs. She had noticed no sphincter disturbance. Pain in the back was very slight.

EXAMINATION.-The patient was a healthy-looking girl and, except for acne vulgaris of the face and back, was of normal physique. There was some hypalgesia below the tenth thoracic nerves on both sides, becoming more marked below the knees and without sacral sparing. Vibration sense was impaired in both legs, and position sense diminished at the right ankle and in the toes of both feet. The abdominal reflexes were absent.

There was marked spasticity and diminution of voluntary power in all muscle groups of both legs, the left leg being more affected than the right. Tendon reflexes in the legs were all exaggerated and ankle clonus was present on the left side. The left plantar response was pathological, the righţ absent. $X$-ray examination showed typical hæmangiomatous changes in the tenth thoracic vertebra (Fig. 5).

Lumbar puncture was not performed because of the acne of the skin of the lower back, and operation was deferred for some weeks on the same account.

Operation.-When Professor Jefferson operated on Oct. 29, 1942, the spines and laminæ of the ninth to the eleventh thoracic vertebræ were exposed and removed. The lamina of the tenth thoracic vertebra was abnormally hard and vascular, and when it had been removed there was found to be a localized excess of firm epidural tissue beneath, through which coursed large venous channels. This epidural tissue was removed piecemeal, whereupon the dura itself was found to be pulsating normally and it was not opened. The wound was closed in the usual manner.

The operative specimen was submitted to Dr. E. Pollak of the University Department of Neuropathology at Manchester Royal Infirmary, who reported as follows on its microscopical appearance :

"Small bits of bone and of infiltrated soft tissue haveop been submitted. The bone itself shows various signs of $\frac{P}{\mathrm{P}}$ destruction : the finer lamellar structure is disturbed, anda osteoclastic activity is visible everywhere. Between the splinters of bone there are islands of neoplastic tissue filled with more or less differentiated vascular formations -0 The infiltrated soft tissue comprising the epidural part of the tumour shows in some places very obvious dediffer $\frac{0}{7}$ entiation with little formation of mature blood-vessef tissue. On the other hand there are areas elsewhere of a higher degree of differentiation where the vessels are well formed and filled with blood vessels, while the walls themselves are often thick and rather cellular in their structure. The calibre of the vessels varies, and in places there is a very dense vascular pattern with more or less interstitial tissue, the cells of which are mostly endothelial (Figs. 3 and 4). The histological diagnosis is of hæmangioendothelioma of the spine and epidural space."

The patient made a good recovery from this intervention and when transferred to Christie Hospital, Manchester, for deep $x$-ray therapy a month later she was somewhat improved, with less spasticity. Ankle clonus was no longer present and power was augmented, especially at the ankle joints.

When seen again in July, 1943, she was back at work in a factory. By this time her tendon reflexes were no longer exaggerated and both plantar responses were flexor, but the left leg was still weak, and appreciation of pin-prick was not quite normal below the knees. $X$-ray examination showed no alteration of the hæmangiomatous vertebra.

The patient's last visit was in July, 1947. She then reported that in 1944 she had had to give up her work because there was a lot of standing and running about to 
be done, and her left leg had let her down several times in a couple of months. Shortly after this, however, she had got married, and was now able to do a full day's housework without any pain in the back or weakness of the legs. She could walk two miles comfortably. On examination she was found to be in very good general condition with a normal range of back movements. The gait was normal, and there was no objective weakness in any muscle group of either leg. There was slight subjective hypoalgesia in the right leg in the area of the second lumbar to the first sacral dermatomes. Other modalities of sensation were perfectly preserved. Sphincter control was reported to be quite normal. $X$-ray 'examination showed a slight increase in density of the body of the tenth thoracic vertebra but no other change (Fig. 6) from the situation revealed five years before.

Case 4: Vertebral and Epidural Hæmangioma.A woman aged 34 was referred from the Maternity Unit at St. Mary's Hospital, Manchester, on Dec. 21, 1946, in the thirty-sixth week of her third pregnancy. She stated that her first pregnancy had been uneventful, but that in 1943, towards the end of her second pregnancy, she had been troubled by severe girdle pains round the lower chest. These pains, however, had disappeared five days before labour and she had thought no more about them. In the thirty-second week of her present pregnancy the same pains had started again. She had found relief from standing up, but had been made worse by lying flat, stooping, or coughing. She said that she had often had to get up and walk about the room at night to ease the pains.

Two weeks later her legs began to feel numb and cold, and to tingle. Simultaneously the left leg seemed to lose power, to be followed by the right leg in the next few days. Ten days before admission she had barely been able to walk half a mile, and five days after this she had been able to do her housework only by dragging herself from one piece of furniture to the next. Finally that same day she collapsed on her bed and could not get up at all. Next day she developed dribbling incontinence of urine and noticed that she was beginning to pass flatus if she coughed or tried to sit up. The girdle pains in the chest were by now very severe indeed and associated with a slight ache between her shoulder-blades.

Examination.-The patient was a tall, obese woman. There was a 36-weeks' pregnancy, the presentation being by the breech. Below the level of the sixth thoracic dermatome there was complete loss of posterior column sense, and pin-prick was appreciated either as blunt or occasionally as a diffuse tingling. There was no sacral sparing. Light touch was slightly impaired in the left thigh and below both knees, but was normal elsewhere. Abdominal and anal reflexes were absent. The abdominal muscles were paralysed.

Both legs were very spastic, with bilateral clonus at knee and ankle and extensor plantar responses. There was weak action against gravity in all muscles of the right leg, but in the left voluntary movement was only detected in the glutæi and the adductors of the thigh, and occasional flexor spasms occurred. Sphincter control was quite absent.
Lumbar puncture showed a pressure of $60 \mathrm{~mm}$. There was a complete block to Queckenstedt's test but a slow rise and fall on abdominal compression. The fluid showed $120 \mathrm{mg}$. of total protein per $100 \mathrm{c.cm}$. and a slight increase in globulin. It was clear and colourless and contained 2 leucocytes per c.mm.

Radiographs of the thoracic spine showed no gross bony abnormality, but the examination was difficult because of the patient's size and pregnancy, and the resultant pictures were not entirely satisfactory.

A preoperative diagnosis of intraspinal hæmangioma was made.

Operation.-At operation on Dec. 21, 1946, by Professor Jefferson, the spines and laminæ of the fourth to sixth thoracic vertebræ were exposed. It was noticed that the bone itself was harder than normal and bled very profusely. Eventually the laminæ were removed and the whole of the epidural space was seen to be covered by a network of huge tortuous veins, two of which burst spontaneously. Under the circumstances no biopsy of the epidural tissue could be made, but the diagnosis of hæmangioma was obvious. After hæmorrhage had been arrested with fibrin foam the wound was closed.

Immediately after this intervention the patient's neurological condition was unchanged. On Dec. 26 she went into labour and was transferred back to St. Mary's Hospital, Manchester, where she was delivered spontaneously of a healthy male child weighing $7 \frac{1}{2} \mathrm{lb}$. The next day she developed acute dilatation of the stomach, collapsed suddenly, and died in the early hours of Dec. 28.

Only a very limited autopsy was permitted, but Dr. Pollak reported as follows on a specimen of bone obtained at operation and on some pieces of epidural tissue removed post mortem.

"The vertebra itself is invaded by a tumour of the hæmangiomatous type (Fig. 7). Spicules of lamellar bone are filled with islands of tumour tissue, the bone is undergoing some degeneration, and osteoclastic activity is very pronounced. The blood-vessel tumour is very well differentiated in appearance, the bony canals being filled with large blood vessels which are dilated, thin-walled, and stuffed with erythrocytes. The overlying epidural tissue shows a tumour which is in the main similar, though here and there are areas of a less differentiated character in which the number of endothelial cells is much greater than in the main mass of the neoplasm (Fig. 8). The spinal cord presents extensive degenerative changes, especially in the white matter, with swelling of the axons and degeneration of the myelin, but no true necrosis of a transverse type. No hæmangiomatous changes can be seen. The histological diagnosis is of hæmangioma of the spine and epidural space."

Case 5 : Epidural Hæmangioblastoma.-A 46-year-old plumber was admitted on June 12, 1946. He gave a two months' history of a feeling of pins and needles radiating from the lumbar region down the left leg. Within a few days the left leg, and then the right, had started to become weak. Early in June he had gone to bed one night and woken up to find his legs so weak that 
he could no longer stand, and within another seven days he had lost all movement and sensation in both legs. Meanwhile he was finding difficulty in micturition, but without any episodes of acute retention. There was no complaint of pain in the back at any time.

EXAMINATION.-Back movements were full and painless. There was a complete loss of all function below the seventh thoracic segment on both sides, except that there was a trace of urethral and rectal sensation and of sphincter control. Flexor spasms occurred frequently in both legs. There were extensive third-degree sacralpressure sores.

$X$-ray examination of the spine showed no definite abnormality. Lumbar puncture revealed a pressure of $160 \mathrm{~mm}$. with a block to Queckenstedt's test and a protein content of $250 \mathrm{mg}$. per $100 \mathrm{c.cm}$. There was no increase in cell count and the Wassermann reaction was negative.

OPERATION.-Operation had to be postponed for many weeks because of the severe pressure sores. It was eventually performed on Oct. 31, 1946, by Mr. F. K. Kessel. A laminectomy of the seventh to tenth thoracic vertebræ was performed. The epidural space contained a greyish-red tumour $1 \mathrm{~cm}$. thick apparently completely surrounding the dura. The dorsal part of this tumour was completely removed but its anterior limit could not be accurately established owing to hæmorrhage and the difficulty of access. However, the cord was now found to be pulsating normally within the dura, which was accordingly not opened, the wound being reformed in layers.

Dr. Pollak reported on the specimen of tumour removed :

" The tissue submitted consists of a tumour which extends into the epidural fat. The main bulk of the neoplasm is formed by more or less differentiated elements of blood-vessel tissue. There are some areas, however, where no proper differentiation of vessels occurs and the whole field is occupied by cells of endothelial character (Fig. 9). Mixed with areas of this type are other fields where lumina of vessels are recognizable, lumina partly filled with blood cells, partly empty. Where the tumour extends into the epidural fatty tissue, it is much more differentiated and there are hardly any islands of dedifferentiated neoplasm. The number of blood vessels there is very much increased and their walls are much thicker than normal (Fig. 10). The histological diagnosis is of epidural hæmangioblastoma."

Neurological recovery after this intervention was extremely slow, although a lumbar puncture performed on Nov. 19, 1946, showed no block to Queckenstedt's test. A course of deep $x$-ray therapy was given later in the same month, but without any dramatic benefit. By January, 1947, however, the patient had regained some appreciation of deep pressure and pin prick on both legs, and six months later he had just sufficient voluntary power in his legs to be able to stand while holding on to a fixed bar in the gymnasium. At the time of writing he has regained control over the right foot and toes, and no longer has any difficulty in initiating the act of micturition, but the left leg is still very weak and spastic.
Case 6: Epidural Hæmangioma.-A woman of 58 was first seen by Mr. W. R. Henderson at the General Infirmary at Leeds on Dec. 31, 1946. Six months before she had a sensation of numbness and tingling on the front of the right thigh, which gradually spread down to the right foot and into the left foot as well. Two months later the same sensations extended up to the lower abdomen, and a month later still she found that she had to walk more slowly than was her habit.

Three months ago this difficulty in walking, which was by now associated with considerable stiffness of both legs, began to get rapidly worse and she found she was no longer able to walk for more than twenty minutes at a time, and she became very tired if she stood for long. For the three weeks before the consultation she had been kept in bed, with some resultant diminution in the numbness of the abdomen and legs.

There was a slight degree of hesitancy of micturition but no other sphincter disturbances. A history of a period of diplopia lasting three weeks and occurring fourteen years ago was elicited, but there was no suggestion of previous trouble with the legs or of mistiness of vision.

EXAMINATion.-There were no neurological abnormalities in the cranial nerves or arms. The abdominal reflexes were all absent but there was no sensory level on the trunk. There was no tenderness or deformity of the spine.

In the legs there was some increase in tone of the proximal muscles, more on the right than the left, with? a sustained patellar clonus on the right side. Distallye there was some weakness of the ankles and more of the toes, with marked impairment of the appreciation of joint movements and tuning fork as high as the ankleso The gait was spastic and the patient could hardly raise herself on her toes. $X$-ray examination of the spine was negative.

Lumbar puncture three weeks before had shown a pressure of $145 \mathrm{~mm}$. with a free rise (to over $300 \mathrm{~mm}$.) on jugular compression, but the pressure then fell only to $245 \mathrm{~mm}$. The cerebrospinal fluid contained $250 \mathrm{mg}$. of protein per $100 \mathrm{c} . \mathrm{cm}$. and 5 leucocytes per c.mm. At the present examination it showed a pressure of $60 \mathrm{~mm}$. with no rise at all op jugular compression.

Myelography was then performed by the lumbar route. It showed a complete arrest of the opaque medium at the level of the sixth to the seventh thoracic vertebræ, and exploration was accordingly resolved upon.

OPERATION.-At operation on Jan. 7, 1947, by Mr. W. R. Henderson, the spines of six and the lamina of five vertebræ were removed through an incision centering on the sixth thoracic spine, the bone appearing normal. This revealed a well encapsulated, dark red, lobulated swelling, measuring $6 \times 2 \times 1 \mathrm{~cm}$., lying in the dorsal part of the epidural space and extending from the fifth to the seventh thoracic vertebra. It tended to extend into the epidural foramina (cf. Case 1), and received several large veins from the deep surface of the laminæ overlying it.

This tumour was completely removed from the underlying dura, from which it could be separated by blunt dissection. After some rather brisk hæmorrhage from enlarged veins near the intervertebral foramina had 

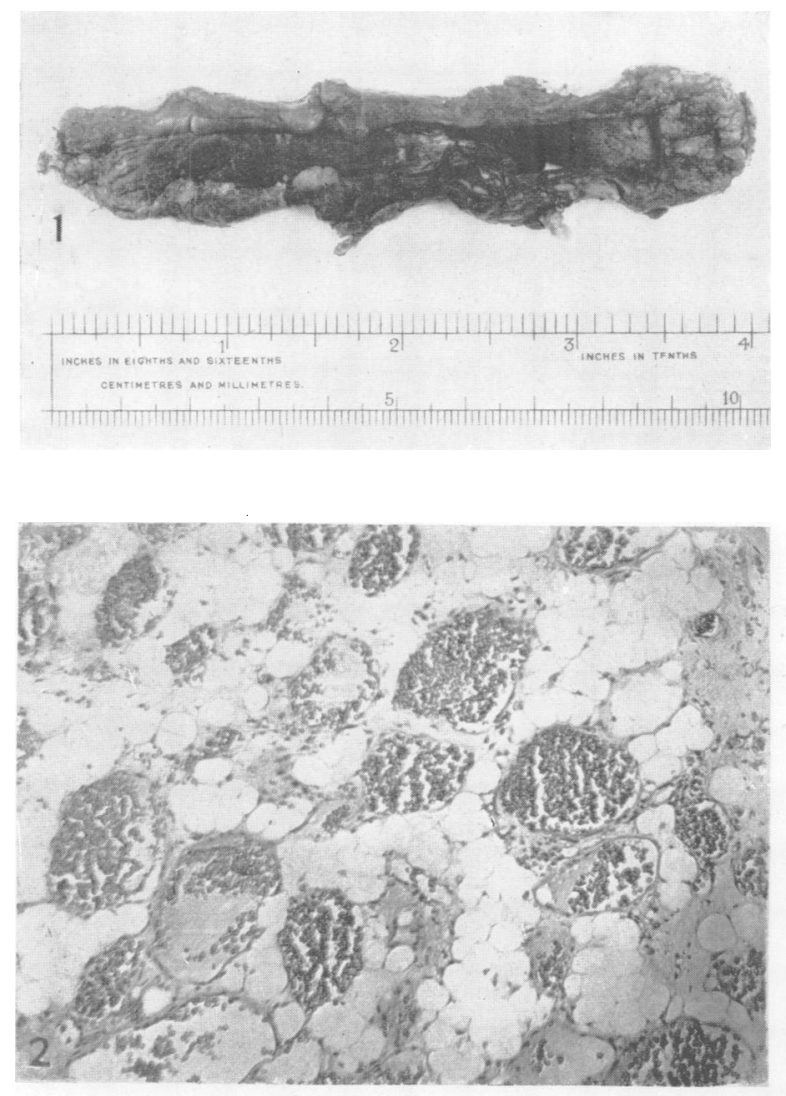

Fig. 1.-Case 1. Specimen removed at operation. Note the lateral extensions of the tumour, corresponding to the sites of the intervertebral foramina.

Fig. 2.-Case 1. Low-power microphotograph, showing typical large blood-spaces with intervening fatty tissue. Hæmatoxylin and eosin.

Fig. 3.-Case 3. A portion of the epidural tissue adjacent to the hæmangiomatous vertebra. Above are well formed, thick-walled blood vessels; below, a less differentiated area. Hæmatoxylin and eosin. $\times 45$.

Fig. 4.-Case 3. High-power view of part of the same field. Hæmatoxylin and eosin. $\times 110$.
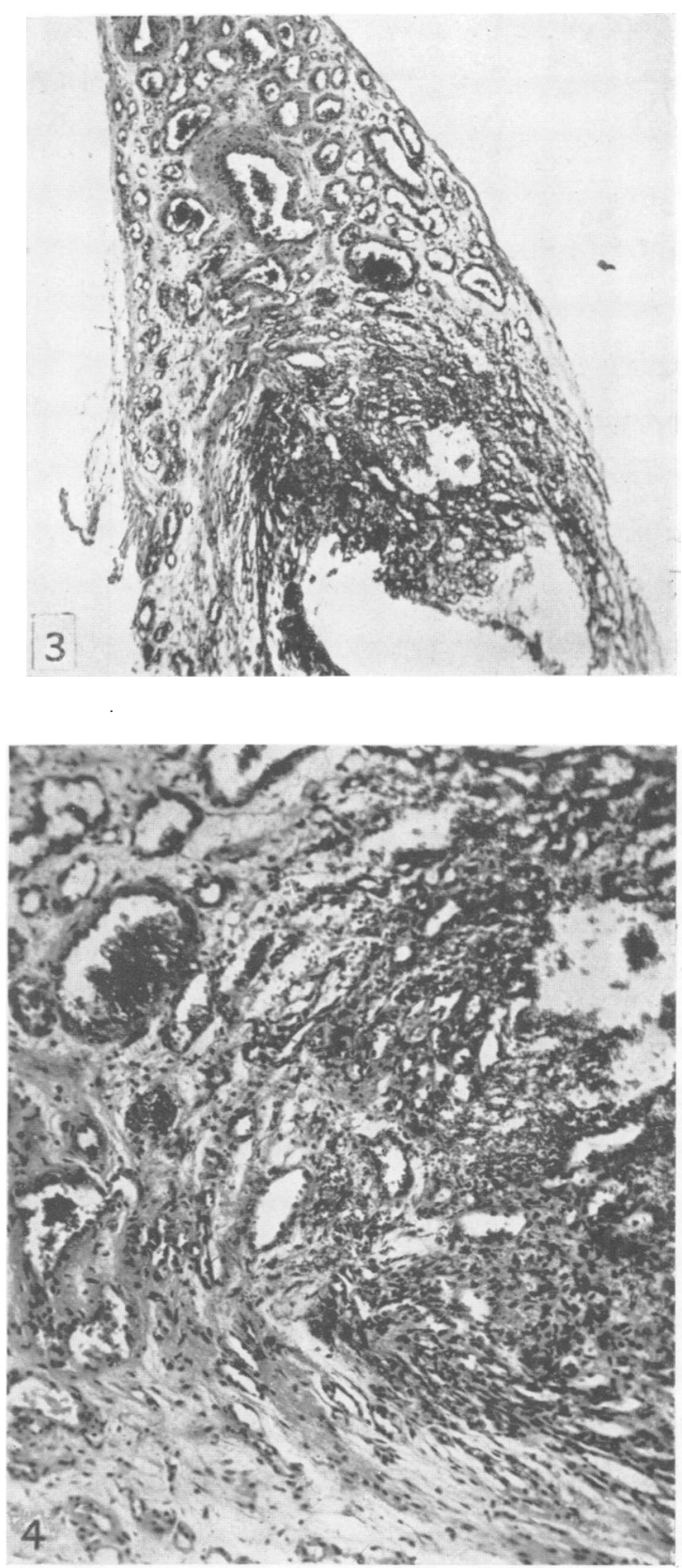
Fig. 5.-Case 3. Preoperative $x$-ray appearance, October, 1942. The tenth thoracic vertebra is slightly expanded and shows the striations typical of a hæmangioma.

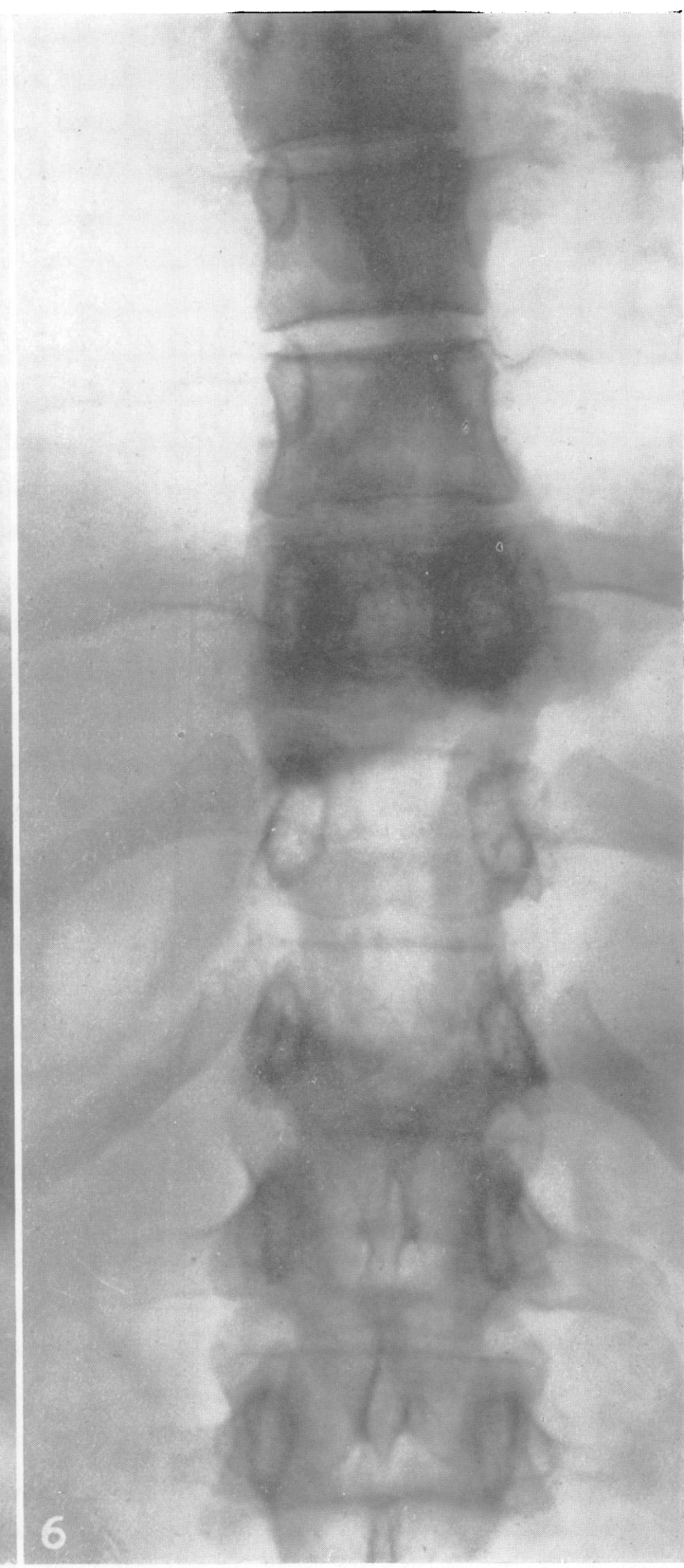

Fig. 6.-Case 3. $X$-ray appearance, October, 1947. There is slightly increased density of the body of the tenth thoracic vertebra. 


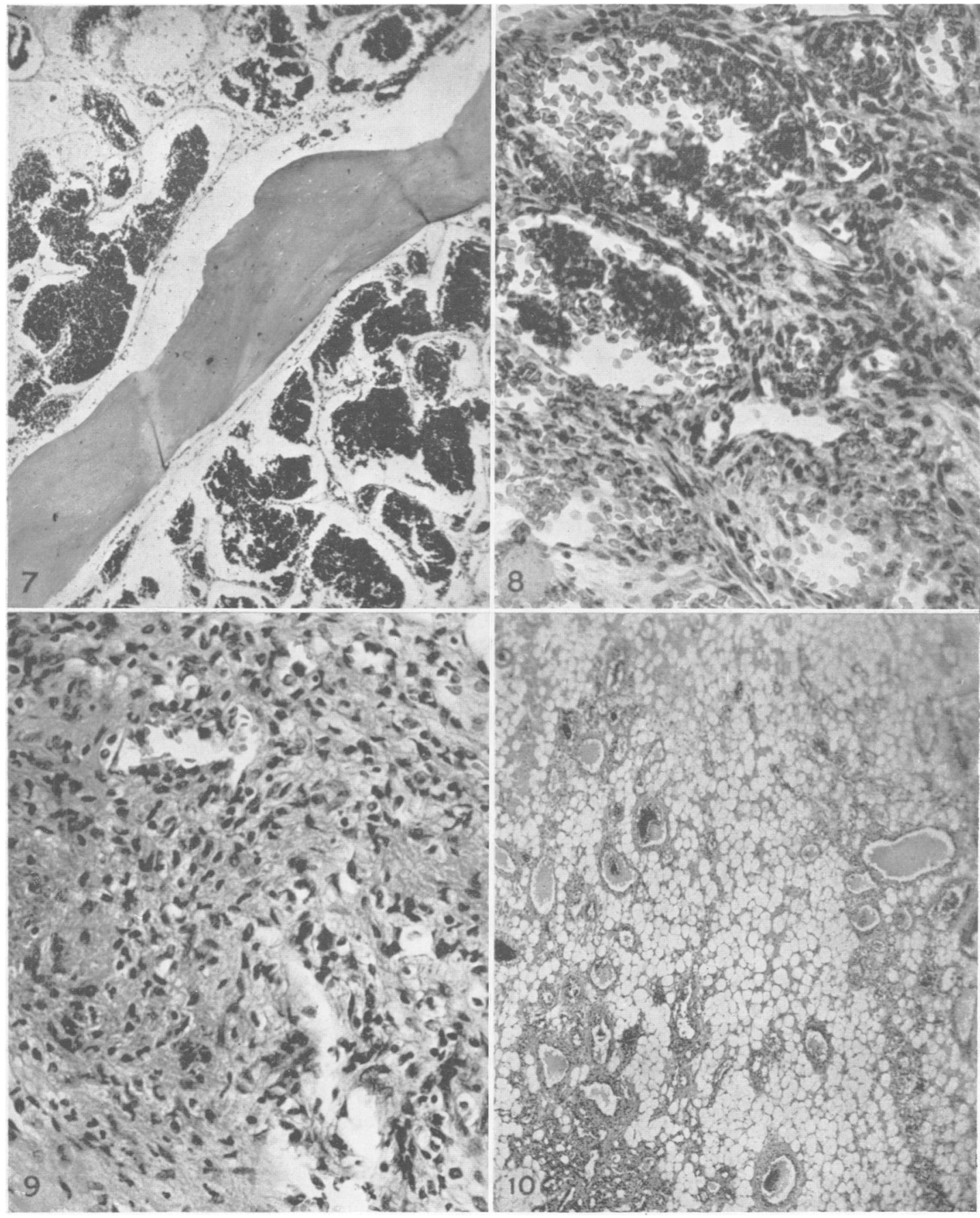

FIG. 7.-Case 4. A section of part of the body of the fourth thoracic vertebra, showing a bony trabecula surrounded by hæmangiomatous tissue. Hæmatoxylin and eosin, $\times 60$.

Fig. 8.-Case 4. An area of epidural tissue in which there is proliferation of endothelial cells around the blood vessels. Hæmatoxylin and eosin, $\times 160$.

FIG. 9.-Case 5. An area of endothelial cells has completely replaced the normal epidural fat. Hæmatoxylin and eosin, $\times 280$.

Fig. 10.-Case 5. Enlarged, thick-walled blood vessels at the edge of the tumour. Contrast these with the thin-walled blood spaces shown in Fig. 2. Hæmatoxylin and eosin, $\times 20$. 
been controlled, the wound was closed in the usual manner.

Three weeks after the operation myelography was again carried out, as the opaque medium had not been removed at the time of operation. This time there was no hold-up. A week later the patient was able to return home. There was little change in the objective neurological signs but she reported a gratifying disappearance of the feeling of numbness and tingling in the trunk and of stiffness in the legs.

The pathological report on the operative specimen was as follows :

" This tumour is made up of large numbers of endothelial lined spaces, mainly in contiguity with one another, but otherwise separated by adipose tissue. The spaces are filled with red blood cells. The histological diagnosis is of cavernous hæmangioma."

Case 7 : Hæmangioma of Vertebra and of Epidural Space.-A man aged 30 years was first seen by $\mathrm{Mr}$. A. Sutcliffe Kerr in November, 1946. He gave a history of pain in the left knee and weakness of the left lower leg for ten months. The right leg had become weak six months later, and for a month he had noticed some hesitancy of micturition.

ExAmination.-He proved to have spasticity of both legs, with extensor plantar responses and a band of hyperæsthesia in the area of the fifth thoracic nerve. $X$-ray examination of the thoracic spine was negative. Lumbar puncture showed no response to Queckenstedt's test. On this occasion the total protein in the cerebrospinal fluid was $70 \mathrm{mg}$. per $100 \mathrm{c.cm}$., though three weeks later, when the patient was admitted to Winwick Emergency Hospital, it was only $15 \mathrm{mg}$. A myelogram, however, showed a complete block between the second and third thoracic vertebræ.

OPERATION.-At operation by Mr. Kerr on Dec. 4, 1946, the spines and laminæ of the first to the third thoracic vertebræ were removed, revealing a localized vascular epidural tumour resembling a secondary deposit. It was dissected away without difficulty.

The pathological report (Dr. M. E. Sharp) on the tumour and on some fragments of the bone overlying it was as follows : "The epidural tumour consists of a mass of fatty tissue richly supplied with capillary blood vessels of varying sizes, and the bone marrow is replaced by similar fatty tissue containing large thin-walled capillaries. The appearances are those of a hæmangioma of the vertebra and of the epidural space."

The patient made an excellent recovery from the operation and was up and about, with normal sphincter control, within three weeks. He subsequently received a course of deep $x$-ray therapy, and remains well without any neurological signs, though he still gets occasional aching pain in his back and a slight sense of instability of the left knee. He is back at work as an upholsterer.

Case 8: Hæmangioma of the Epidural Space.-A woman aged 45 years was admitted on Sept. 1, 1947, to Walton Hospital, Liverpool, under the care of Mr. A. Sutcliffe Kerr. She gave a history of dull aching pain in the left groin for four years, followed by progressive weakness and numbness of the legs in the last nine months. She had occasionally fallen in the house.
ExAMINATION.-She was found to have spasticity and weakness of both legs, with absent abdominal reflexes and extensor plantar responses. There was hypalgesia and loss of vibration sense below the tenth thoracic dermatome. Lumbar puncture on admission showed $150 \mathrm{mg}$. of protein per $100 \mathrm{c.cm}$. and increased globulin but no block to Queckenstedt's test. A fortnight later, however, the paraplegia suddenly became very much more severe. A further lumbar puncture now showed $1,000 \mathrm{mg}$. of protein per $100 \mathrm{c.cm}$., and a complete block to Queckenstedt's test. Myelography revealed an arrest of the opaque medium opposite the body of the fourth thoracic vertebra.

OPERATION.-The next day the spines and laminæ of the third to fifth thoracic vertebræ were removed. A grey, soft, vascular tumour surrounded by a thin capsule was discovered on the posterior aspect of the spinal dura. It measured $4 \mathrm{~cm}$. in length and extended into the intervertebral foramina, forming quite a large lateral extension between the fourth and fifth thoracic vertebræ on the left side. The tumour was eventually removed intact.

At the time of writing, four months after her operation, the patient is slowly recovering some power in her legs, but is not yet able to stand or walk unaided.

\section{Discussion}

The ætiology of spinal hæmangiomas has been discussed by many of those writers to whom references has already been made. Some have regarded them $\vec{b}$ as pure congenital anomalies, some as true neoplasms while a few have even sought to establish the role of trauma or of syphilis in their production. To this question the present communication can give nos final answer. One can only suggest that these tumours are, as many writers have suggested of hæmangiomas in general, congenital anomalies, but capable of growth : for the histological appearance of the less mature specimens speaks strongly for their being true neoplasms, while the number of small inert hæmangiomas which may be found among subjects of all age-groups at routine autopsy-in Schmorl's laboratory it was more than 10 per cent. of all spines examined-also strongly suggests a congenital defect. Perhaps the truth is that the hæmangiomas arise in the beginning from a dysplasia of the mesoderm of one or more spinal segments and that thereafter their behaviour is governed largely by the activity of the tissues by which they are surrounded. Thus, as the blood supply of bone decreases once growth is complete, so the intravertebral hæmangiomas are usually well differentiated and inert. But the epidural hæmangiomas, growing in a more active medium, are more prone to partial or total blastomatous transformation. All possible grades of this transformation are recorded in the literature and more than one was found even in the small series presented in this paper.

But not only do these tumours vary in the minutiæ 
of their cellular structure. They also show several intermediate stages in situation between the purely vertebral and the purely epidural hæmangiomas. A vertebral tumour may have an epidural extension of greater or less size, an epidural one may be associated with more or less hæmangiomatous change in the vertebræ around it : the only rarity is for the hæmangiomatous process to transgress the barrier of the dura mater.

Possibly an unduly rigid division between the vertebral and purely epidural tumours has sometimes in the past resulted in an imperfect understanding of the pathology of the spinal cord compression to which they may give rise. It is usually stated that cord symptoms may be produced in one of three ways :

1. By collapse of the vertebral body (Deetz, 1901 ; Muthmann, 1903 ; Ewing, 1928 ; Ireland, 1932 ; Boudreaux, 1936 (Fig. 18 (a) and (b)) ; Zdansky, 1936).

2. By expansion of the affected bone causing a diffuse narrowing of the spinal canal without any element of collapse. That this is the commonest cause of cord symptoms is suggested by the work of Schlezinger and Ungar (1939) and of Ghormley and Adson (1941). Several cases which have sometimes been referred to in the past as of "epidural extensions" of vertebral hæmangiomas (Perman, 1926; Bailey and Bucy, 1929; Roith, ${ }^{1} 1931$; Clavelin and Gauthier, 1932) are almost certainly to be placed in this group.

3. By the protrusion of a mass of tissue of varying degrees of hardness from the affected vertebra into the epidural space (Gerhardt, 1895 ; Ribbert, 1912 ; Trommer, 1919-20 ; Gold, 1926 ; G. Guillain and others, 1928 ; Jiano and others, 1931 ; Junghanns, (1932 b) ; Fumarola and Enderle, 1934 ; Boudreaux, 1936 (Obs. 2) ; Clausnizer, 1937 ; Karshner and others, 1939 ; de Gispert Cruz and Tolosa, 1943 ; Shenkin and others, $1945^{2}$ ). Almost all these cases betrayed their vertebral origin by containing spicules of bone or by being covered by periosteum. The protrusion sometimes takes the form of a small nodule, and sometimes of a finger-like projection several $\mathrm{cm}$. in length which grows upward or downward in the spinal canal.

But as Elsberg (1941) has pointed out, citing a personal experience, there is a further small group of cases in which a hæmangioma of the spinal epidural space occurred in conjunction with a vertebral hæmangioma and caused symptoms of cord compression. Other examples would appear to have occurred in the cases recorded by Hille (1924),

\footnotetext{
1 This case was also recorded from the pathological point of view by Scherer (1933).

2 The case of a vertebral hæmangioma with epidural " granulation tissue" reported by Hammes (1933) is probably similar.
}

Connell and Hay (1930), Alpers and Pancoast (1932), Boudreaux (1936, Obs. 1), and certainly in the present Cases 4 and 7. Sometimes the degree of bone invasion was found to be slight, as in Connell and Hay's (1930) case, while in other cases the whole vertebra was involved; but in no instance was there any suggestion that tissue from the affected vertebra itself had been extruded into the epidural space. Rather, the neoplastic process was involving both vertebra and epidural tissue.

Unfortunately from the statistical point of view, cases of vertebral hæmangioma with cord compression are often treated by radiotherapy without biopsy or exploration, so that the exact pathology of the compressing agent remains unverified and therefore the relative frequency of the four types of compression which have been described cannot be accurately assessed.

The clinical signs of the hæmangiomas of the epidural space, whatever their exact point of origin, have been those of progressive paraplegia of varying rapidity of onset, but usually developing within a few months. In Johnston's (1938) case the paraplegia was both sudden and complete- and was shown at autopsy to have resulted from a spontaneous epidural hæmorrhage from the vessels of the tumour. Unfortunately this event was not associated either with a complete block to Queckenstedt's test or with a significant elevation of cerebrospinal fluid protein, and laminectomy was therefore not performed. A period of premonitory pain in the back has, as might be expected, occurred more frequently in those cases where the body of the vertebra was involved. Sacral sensory changes and sphincter disturbances were prominent in some cases but totally absent in others ; root pains were similarly inconstant. Cutaneous hæmangiomas were only found in three cases (Devic and Tolot, 1906; Johnston, 1938; Kaplan, 1942) and pigmented nævi of the skin of the back once (Karshner and others, 1939). Hæmangiomas of the liver and spleen were occasionally found in the cases which came to autopsy. In Devic and Tolot's (1906) case of a purely epidural hæmangioma the cord compression seems to have been due at least in part to an associated intradural but extramedullary tumour which, after some discussion, the authors termed an angiosarcoma. This interpretation of the tumour has been accepted by subsequent writers, but the original description and drawing of the histological preparation suggest very strongly that the intradural neoplasm was in fact a meningioma, though an extradural cavernous hæmangioma was also present.

In two cases in the literature a vertebral hæmangioma was present without being the cause of the spinal cord symptoms of which the patient com- 
plained. Saltykow (1909) reported a vertebral hæmangioma with a small epidural extension in a patient dying of advanced tuberculosis involving other vertebræ. He himself believed that the hæmangioma was too small to have caused a paraplegia. In Sandahl's (1931) case a vertebral hæmangioma was a purely incidental finding and the symptoms arose from a " neurinoma" attached to a nerve root, which was successfully removed.

In two cases a previously symptomless epidural hæmangioma has apparently shared in the general venous engorgement of pregnancy and has thus come to cause temporary paraplegia. The first was the case recorded by Balado and Morea (1927), of a woman of 36 who gave a history of paralysis of the legs towards the end of six out of seven pregnancies. On four occasions the symptoms had cleared up immediately after labour, and in the remaining two had lasted respectively one month and five months afterwards. She came under observation at the end of the eighth pregnancy, paraplegia being again far advanced, but she died of heart failure before delivery. At autopsy an epidural angiolipoma was found which extended from the second to the seventh thoracic vertebræ. The second example, the present Case 4, is very similar. Such a history of successive attacks of paraplegia over a period of years with complete remissions between them might in future be regarded as suggestive of an intraspinal hæmangioma. Otherwise the diagnosis is unlikely to be made without operation except where radiological evidence of a hæmangioma of the vertebræ is present or in those very few cases where cutaneous hæmangiomas are found.

From the anatomical and symptomatological point of view the present communication has tended to minimize the difference between the vertebral and the purely epidural hæmangiomas. In respect of treatment, however, the two groups present rather different problems. The purely epidural tumours require exploratory operation, without which the diagnosis can never be made with certainty and cannot always even be suspected. The results vary with the histological nature of the tumour. Of twelve cases of mature hæmangioma submitted to operation (nine in the literature and three in the present series) the tumour was removed in ten, with one postoperative death. Of the cases which survived, one is too recent to assess but the other eight showed a gratifying degree of neurological improvement. There is no report of a recurrence of symptoms in this group. Of the two cases in which the tumour was too vascular to be removed, one was unimproved by operation but one survived twelve years much improved by the decompression afforded.
Of fourteen cases of epidural hæmangioendothelioma and hæmangioblastoma which were submitted to operation two died in the immediate postoperative period. Six of the remainder received no further treatment, of which one was unchanged, three were improved, and two had a recurrence of symptoms within two years.

The remaining six received radiotherapeutic treatment as well, and again one was unchanged, three were improved, and two suffered a recurrence within two years. However, although these figures hardly demonstrate the value of radiotherapy, it should be added that in the group untreated by radiotherapy the recorded period of freedom from recurrence are in all cases less than two years, while in the three treated cases the periods of freedom were five, eight, and eleven years respectively. It would, therefore, seem wise to leave open at present the question of the use of radiotherapy in treating this condition.

In the case of vertebral hæmangiomas with cond symptoms the problem is rather different. A correct diagnosis can usually be made without operation, because of the presence of typical $x$-ray changes in the affected vertebra, and it is well establishedo that, as Nattrass and Ramage (1932) and Ireland (1932) originally showed, radiotherapy can relieve $\frac{}{\Phi}$ cord symptoms as well as those due to local changes in the bone itself. The long-term results of radiotherapeutic treatment are good. Ferber and Lampe (1942), for example, reported that twelve out of thirteen cases were substantially improved for a period of years, whereas operation has only secured 50 per cent. of neurological recoveries and has carried a mortality of 20 per cent.; though it should be pointed out that many of the recorded cases were operated upon in the days before modern methods of resuscitation were available.

There is one real hazard of radiotherapy, which is illustrated by the experience of Freedman (1940), who recorded a case in which a partial cord lesion due to a vertebral hæmangioma progressed rapidly to completeness during a course of deep $x$-ray treatment. The situation was saved only by immediate laminectomy. One may therefore tentatively suggest that there is still a place for preliminary decompression by laminectomy in cases where paraplegia is far advanced, lest the reaction to radiotherapeutic treatment should cause complete and irrecoverable cord damage. And there is one other occasion on which operation seems to be strongly indicated, and that is when the paraplegia is of sudden onset. For this event has twice (Johnston, 1938 ; Kaplan, 1942) been found to be due to a spontaneous epidural hæmorrhage. But except in these cases-and of course those like the present 
Case 4, in which radiological methods have failed to establish the nature of the compressing lesion-the advocates of radiotherapy for vertebral hæmangioma, with or without cord symptoms, seem to have proved its efficacy as the standard method of treatment, while the role of operation is a subsidiary one. The clinician must make an individual judgment on the merits of each case, not forgetting that total extirpation of vertebral hæmangiomas by operation is rarely, if ever practicable.

\section{Summary}

1. The literature relating to hæmangiomas of the spinal epidural space, including those which arise from the vertebræ, is surveyed and eight cases are recorded.

2. Comment is made upon ways in which vertebral and epidural hæmangiomas can cause spinal cord compression.

3. The clinical features are discussed, and a rare syndrome of remittent attacks of paraplegia occurring during pregnancy is mentioned as characteristic of an intraspinal hæmangioma.

4. Some points regarding treatment and prognosis are noted.

My grateful thanks are due to Professor Geoffrey Jefferson, C.B.E., for his help and encouragement in the preparation of this paper, and to Professor Norman Dott, Mr. W. R. Henderson, Mr. A. Sutcliffe Kerr, and Mr. F. K. Kessel, for permission to record the cases seen by them. Dr. E. Pollak has been painstaking in the examination of the pathological material.

Most of the photomicrographs were made in the Manchester University Department of Pathology, by kind permission of Professor S. L. Baker.

\section{REFERENCES}

Alpers, B. J., and Pancoast, H. K. (1932). Surg. Gynec. Obstet. 55, 374.

Antoni, N. (1936). In Bumke-Foerster's “ Handbuch der Neurologie." Springer. Berlin. 10, 70.

Bailey, P., and Bucy, P. C. (1929). J. Amer. med. Ass., 92, 1748.

Balado, M., and Morea, R. (1927). Arch. argent. neurol., $1,345$.

Bériel, L. (1922). Lyon Méd., 131, 777.

Boudreaux, J. (1936). "Les Tumeurs Primitives du Rachi." Vigot Frères. Paris. p. 137.

Bucy, P. C. (1932). Surg. Clin. N. Amer., 12, 1323.

Clausnizer, H. (1937). Dtsch. Z. Nervenheilk. 142, 276.

Clavelin and Gauthier. (1932). Rev. Chir., Paris, 70, 308.

Connell, W. T., and Hay, W. D. (1930). Canad. med. Ass. J., $22,75$.

Cornil, L., and Mosinger, H. (1932). Ann. d' anat. path., 9, 955.

Dandy, W. E. (1925). Ann. Surg., 81, 223.
De Gispert Cruz, I., and Tolosa, E. (1943). Rev. Clin. Españ., 9, 197.

Deetz, E. (1901). Münch. med. Wschr., 48, 1506.

Devic, E., and Tolot, G. (1906). Rev. Méd. Paris. 26, 255.

Dott, N. M. (1947). Personal Communication.

Elsberg, C. A. (1941). " Surgical Diseases of the Spinal Cord." H. K. Lewis. London. p. 331.

Ewing, J. (1928). “"Neoplastic Diseases." Third Edit. Saunders. Philadelphia. p. 249.

Ferber, L., and Lampe, I. (1942). Arch. Neurol. Psychiat . Chicago. 47, 19.

Freedman, E. (1940). Clin. Bull. Western Reserve Univ., 4, 34. Quoted by Ferber and Lampe (1942).

Fumarola, G., and Enderle, C. (1934). Z. ges. Neurol. Psychiat., 150, 411.

Gerhardt. D. (1895). Dtsch. Z. Nervenheilk, 6, 127. Ghormley, R. K., and Adson, A. W. (1941). J. Bone Jt. Surg., 23, 887.

Globus, J. H., and Doshay, L. J. (1929). Surg. Gynec. Obstet., 48, 345.

Gold, E. (1926). . Arch. klin. Chir., 139, 729.

Grapiolo, A., and Morea, R. (1944). Prensa méd. argent. $31,319$.

Guillain, G., Decourt, J., and Bertrand, I. (1928). Ann. Méd., 23, 5.

Guillain, P. (1933). Thése de Paris. Quoted by Boudreaux (1936).

Hammes, E. M. (1933). Arch. Neurol.Psychiat., Chicago, 29, 1330.

Hille, K. (1924). Münch. med. Wschr., 71, 1241.

Ireland, J. (1932). Amer. J. Roentgen., 28, 372.

Jiano, J., Grigoresco, D., and Vasiliu, D. (1931). J. Chir., Paris, 38, 652.

Johnston, L. M. (1938). J. Amer. med. Ass., 110, 119.

Junghanns, H. (1932a). Arch. klin. Chir., 169, 204. (1932b). Ibid., 169, 321.

Kaplan, A. (1935). J. Mt. Sinai Hosp., 2, 64.

(1942). Amer. J. Surg., 57, 450.

Karshner, R. G., Rand, C. W., and Reeves, D. L. (1939). Arch. Surg., 39, 942.

Liebscher, C. (1901). Prag. med. Wschr., 26, 189.

López Ibor, J. J., and Peraita, M. (1941). Actas Españ. Neurol. Psiquiat., 2, 93.

Mixter, W. J. (1932). Dean Lewis's "Practice of Surgery," 12, 54.

Muthmann, A. (1903). Virchows Arch. path. Anat., $172,324$.

Naffziger, H. C., and Brown, H. A. (1933). Arch. Neurol. Psychiat., Chicago. 29, 561.

Nattrass, F. J., and Ramage, D. (1932). J. Neurol. Psychopath., 12, 231.

Perman, E. (1926). Acta. chir. scand., 61, 91.

Petit-Dutaillis, D., and Christophe, J. (1931). Rev. Neurol., 2, 824.

Rand, C. W. (1927). Arch. Neurol. Psychiat., Chicago., 18, 755.

Rasmussen, T. B., Kernohan, J. W., and Adson, A. W. (1940). Ann. Surg., 111, 513.

Ribbert, H. (1912). Dtsch. med. Wschr., 38, 390.

Roith, O. (1931), Zbl. Chir., 58, 3028.

Saltykow, S. (1909). Verhandl. deutsch. Path. Gesellsch. Leipzig. p. 370 . 
Sandahl, C. (1931). Acta chir. scand., 69, 63.

Scherer, E. (1933). Beitr. path. Anat. allg. Path., 90, 521. Schlezinger, N. S., and Ungar, H. (1939). Amer. J. Roentgen., 42, 192.

Shenkin, H. A., Horn, R. C., and Grant, F. C. (1945). Arch. Surg., 51, 125.

Trommer, B. (1919-20). Frankf.Zr. Path., 22, 313.
Turner, O. A., and Kernohan, J. W. (1941). Arch. Neurol. Psychiat., Chicago, 46, 444.

Wyburn-Mason, R. "(1943). "The Vascular Abnormalities and Tumours of the Spinal Cord and its Membranes." Henry Kimpton. London. Passim. Zdansky, E. (1936). Fortsch. Geb. Röntgenstrahlen, $54,263$.

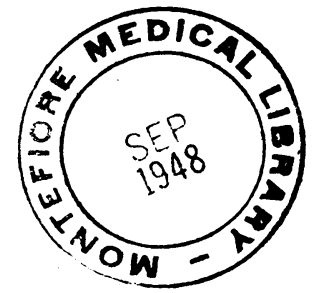

